\title{
ANALISIS BIOAUTOGRAFI KROMATOGRAFI LAPIS TIPIS DAN AKTIVITAS ANTIBAKTERI EKSTRAK ETANOL BAWANG TIWAI (Eleutherine bulbosa (Mill.) Urb.) TERHADAP Methicillin-resistant Staphylococcus aureus (MRSA)
}

\author{
Swandari Paramita ${ }^{1, *}$, Yadi Yasir ${ }^{2}$, Yuniati Yuniati ${ }^{2}$, Ibnu Sina ${ }^{3}$ \\ ${ }^{1}$ Laboratorium Kedokteran Komunitas, Fakultas Kedokteran, Universitas Mulawarman \\ ${ }^{2}$ Laboratorium Mikrobiologi, Fakultas Kedokteran, Universitas Mulawarman \\ ${ }^{3}$ Program Studi Pendidikan Dokter, Fakultas Kedokteran, Universitas Mulawarman \\ *Corresponding author email: swandariparamita@gmail.com
}

\begin{abstract}
Methicillin-resistant Staphylococcus aureus (MRSA) infections are the major health problem in Indonesia; this is mainly due to their resistance to antibiotics. Based on this, the quest for new sources of natural based antimicrobial drugs is necessary. Bawang tiwai (Eleutherine bulbosa (Mill.) Urb.) is one of the natural materials that have potential as an antibacterial natural-based of Indonesia origin. Bawang tiwai already used empirically by local communities in East Kalimantan to treat various diseases. The aim of this research is to know the antibacterial activity of E. bulbosa ethanol extract on MRSA and to know the type of secondary metabolite with antibacterial activity tested by TLC bioautography method. The experiment was conducted on Research Laboratory, Faculty of Medicine, Mulawarman University, Samarinda. TLC results showed that ethanol extract of E. bulbosa has compounds containing sugar, alkaloids, steroids, and flavonoids. The results of TLC bioautography show that ethanol extract of E. bulbosa can inhibit the growth of MRSA. MIC results show that ethanol extract of E. bulbosa has potent antibacterial activity against MRSA with MIC 1 $\mathrm{mg} / \mathrm{mL}$. The conclusion of this research is all the results support the potential of bawang tiwai as the alternative component of natural-based antibacterial agents against MRSA.
\end{abstract}

Keywords: Eleutherine bulbosa, antimicrobial, MRSA, bioautography, thin layer chromatography

\begin{abstract}
ABSTRAK
Infeksi Methicillin-resistant Staphylococcus aureus (MRSA) merupakan masalah kesehatan utama di Indonesia, hal ini terutama karena resistensinya terhadap antibiotika. Berdasarkan hal tersebut maka upaya pencarian komponen antibakteri berbahan dasar alam saat ini menjadi fokus perhatian. Bawang tiwai (Eleutherine bulbosa (Mill.) Urb.) adalah salah satu yang memiliki potensi sebagai antibakteri berbahan dasar alam asli Indonesia. Bawang tiwai secara empiris sudah digunakan masyarakat lokal di Kalimantan Timur untuk mengobati berbagai penyakit. Penelitian ini bertujuan untuk mengetahui aktivitas antibakteri ekstrak etanol MRSA serta mengetahui jenis metabolit sekunder dengan aktivitas antibakteri yang diuji dengan metode bioautografi KLT. Penelitian dilakukan di Laboratorium Riset, Fakultas Kedokteran, Universitas Mulawarman, Samarinda. Hasil KLT menunjukkan bahwa ekstrak etanol E. bulbosa memiliki golongan senyawa yang mengandung gula, alkaloid, terpen-steroid dan flavonoid. Hasil bioautografi KLT menunjukkan bahwa ekstrak etanol E. bulbosa dapat menghambat pertumbuhan MRSA. Hasil KHM menunjukkan bahwa ekstrak etanol E. bulbosa memiliki potensi aktivitas antibakteri yang baik terhadap MRSA dengan angka KHM $1 \mathrm{mg} / \mathrm{mL}$. Kesimpulan penelitian ini adalah seluruh hasil diatas mendukung potensi bawang dayak sebagai alternatif komponen antibakteri berbahan dasar alam terhadap MRSA.
\end{abstract}

Kata kunci: Eleutherine bulbosa, antibakteri, MRSA, kromatografi lapis tipis, bioautografi

Submitted on: 8 November 2017 Accepted on:8 December 2017

DOI: https://doi.org/10.25026/jsk.v1i9.86 


\section{PENDAHULUAN}

Pada tahun 2017 World Health Organization (WHO) mengeluarkan daftar patogen prioritas untuk meningkatkan upaya riset pencarian antibiotik baru, guna mengatasi masalah resistensi antibiotik. Dalam daftar patogen prioritas tersebut terdapat Methicillin Resistant Staphylococcus aureus (MRSA) yang mendapat prioritas tinggi untuk riset pencarian antibiotik baru terhadapnya. MRSA merupakan bakteri yang menjadi perhatian penting terkait infeksi nosokomial di rumah sakit [1]. Infeksi nosokomial merupakan infeksi yang terjadi pada pasien selama menjalani proses perawatan di rumah sakit atau pelayanan kesehatan lainnya, yang tidak muncul atau dalam masa inkubasi pada saat pasien mulai opname. Infeksi nosokomial menyebabkan meningkatnya masalah resistensi antibiotik. Sebagian besar kuman sulit untuk ditangani dengan antibiotik biasa, masalah resistensi antibiotik mempersulit upaya pengobatan pasien tersebut [2].

Alam telah menjadi sumber bahan obat selama ribuan tahun dan sekitar $80 \%$ penduduk dunia mengandalkan pengobatan tradisional untuk menjaga kesehatan mereka. Bahan alam menjadi sumber penting dalam mengatasi masalah kesehatan, hal ini disebabkan adanya bahan bioaktif yang terkandung di dalamnya, seperti alkaloid, tanin, flavonoid dan komponen fenolik. Perkembangan dalam identifikasi sumber bahan alam baru yang memiliki aktivitas antibakteri dapat mendorong temuan antibakteri alternatif [3]. Komponen antibakteri dalam tumbuhan dapat mencegah terjadinya infeksi bakteri melalui mekanisme yang berbeda dari antibakteri komersial yang selama ini ada, yang memiliki efek samping yang tidak diharapkan [4]. Salah satu bahan alam yang akan dikedepankan dalam penelitian kali ini adalah bawang tiwai.

Bawang tiwai atau Eleutherine bulbosa (Mill.) Urb. adalah tanaman herbal yang termasuk dalam famili Iridaceae [5]. Tumbuhan ini secara turun-temurun telah dipergunakan oleh masyarakat Dayak sebagai obat tradisional untuk berbagai jenis penyakit seperti kanker payudara, hipertensi, diabetes mellitus, kolesterol, jantung, dan stroke [6]. Selain itu E. bulbosa juga dipakai untuk disentri, radang usus, peluruh buang air kecil dan besar, anti muntah, anti peradangan, anti perdarahan, antifertilitas, untuk meningkatkan daya tahan tubuh, dan penyembuhan luka. Etnis Dayak menggunakan umbinya untuk melancarkan produksi air susu ibu [7].

Berdasarkan penjelasan di atas, terdapat bukti empiris bahwa E. bulbosa telah digunakan masyarakat lokal untuk masalah kesehatan yang terkait aktivitas bakteri. Selain itu terdapat bukti dari penelitian terdahulu bahwa E. bulbosa terbukti efektif terhadap beberapa jenis bakteri. Maka penelitian ini bermaksud untuk menggali lebih dalam mengenai aktivitas antibakteri E. bulbosa, terutama yang berasal dari metabolit sekundernya, terhadap

Methicillin-resistant Staphylococcus aureus (MRSA).

\section{METODE PENELITIAN}

\section{Waktu dan Tempat}

Penelitian dilakukan pada bulan Mei hingga Oktober 2016. Lokasi pengambilan sampel tumbuhan obat dilakukan di Kabupaten Kutai Timur, Kalimantan Timur. Identifikasi tumbuhan obat dilakukan oleh Laboratorium Dendrologi, Fakultas Kehutanan Universitas Mulawarman. Pengolahan sampel tumbuhan obat dilakukan di Laboratorium Farmakologi, Fakultas 
Kedokteran Universitas Mulawarman. Uji bioautografi KLT dilakukan di Laboratorium Mikrobiologi, Fakultas Kedokteran Universitas Mulawarman.

\section{Pembuatan Ekstrak Tumbuhan Obat}

Simplisia yang telah dihaluskan lalu dimaserasi dengan pelarut etanol. Pada penelitian ini digunakan pelarut etanol absolut. Untuk pembuatan ekstrak, dimasukkan satu bagian serbuk kering simplisia ke dalam maserator dan ditambahkan 10 bagian pelarut. Selanjutnya direndam selama 6 jam sambil sesekali diaduk menggunakan shaker orbital dengan kecepatan 20 rpm selama 10 menit pada suhu kamar, kemudian didiamkan selama 18 jam. Maserat dipisahkan dengan menggunakan kertas saring Whatman dan diulang sebanyak dua kali. Semua maserat dikumpulkan, kemudian diuapkan dengan vakum rotavapor suhu $50^{\circ} \mathrm{C}$ hingga diperoleh ekstrak kental. Kemudian ekstrak yang didapat dikeringkan lebih lanjut dengan dimasukkan dalam desikator yang berisi silika gel biru dalam oven suhu $50^{\circ} \mathrm{C}$. Ekstrak kering disimpan dalam kulkas $-20^{\circ} \mathrm{C}$ sebelum dilakukan penelitian lebih lanjut [8].

\section{Pembuatan Suspensi Bakteri}

Pada penelitian ini digunakan bakteri uji $S$. aureus (MRSA) ATCC 33591. Bakteri uji dibiakkan dalam medium Muller-Hinton broth selama 18 sampai 24 jam. Bakteri yang telah diinkubasi ini kemudian dimasukkan kembali ke dalam media Muller-Hinton broth (1,5 strength) kemudian ditentukan konsentrasinya dengan menggunakan spektrofotometer pada panjang gelombang $625 \mathrm{~nm}$ dengan rentang nilai OD 0,08-0,13 setara dengan standar McFarland 0,5 yang selanjutnya digunakan untuk penentuan kadar hambat minimum (KHM) [9].

\section{Kromatografi Lapis Tipis}

Lempeng KLT yang akan digunakan dipanaskan dalam oven pada suhu $100^{\circ} \mathrm{C}$ selama 30 menit. Ekstrak etanol E. bulbosa ditotolkan pada lempeng KLT menggunakan pipa kapiler, dibiarkan beberapa menit hingga kering lalu dimasukkan ke dalam TLC Chamber (Camag) yang sudah jenuh dengan cairan pengelusi. Dibiarkan terelusi sampai batas lempeng kromatogram yang telah ditentukan. Lempeng dikeluarkan dari TLC Chamber, lalu noda yang tampak diamati di bawah sinar UV dengan panjang gelombang 254 dan $365 \mathrm{~nm}$, kemudian dilakukan penentuan nilai Retardation Factor (Rf). Kromatogram dibuat minimal 5 rangkap untuk setiap eluen yang digunakan, 4 plat KLT akan digunakan untuk identifikasi 4 golongan senyawa yaitu golongan senyawa mengandung gula, golongan alkaloid, golongan terpen-steroid dan golongan flavonoid. Plat KLT yang tersisa digunakan untuk bioautografi KLT untuk melakukan evaluasi aktivitas antibakteri. Pada penelitian ini digunakan 4 macam eluen yang berbeda yaitu; butanol/ asam asetat/ air dengan perbandingan 4:1:5, nheksan/ etil asetat dengan perbandingan $4: 1$, kloroform/ etil asetat/ asam formiat dengan perbandingan 0,5:9:0,5 dan etil asetat/ metanol/ air dengan perbandingan 6:4:2. Setiap cuplikan berisi $10 \mathrm{mcg}$ yang diambil dari $2 \mu \mathrm{L}$ ekstrak tumbuhan obat yang telah dilarutkan dalam pelarut etanol 96\% dengan konsentrasi 10 mg/ml [10].

\section{Bioautografi Kromatografi Lapis Tipis}

Pada penelitian ini metode yang digunakan adalah bioautografi agar overlay. Medium agar broth sebanyak 10 $\mathrm{mL}$ yang sudah dicampur $1 \mathrm{~mL}$ suspensi bakteri bakteri uji S. aureus (MRSA) yang telah disiapkan dalam media agar dituang untuk melapisi lempeng KLT 
yang sebelumnya telah dielusi. Setelah itu lempeng KLT tersebut diinkubasikan pada suhu $37^{\circ} \mathrm{C}$ selama $18-24$ jam. Kemudian dilakukan pencatatan zona hambat yang terbentuk. Setelah dilakukan uji bioautografi KLT dilakukan pemantauan bercak KLT guna mengidentifikasi senyawa apa yang terdapat dalam kromatogram hasil elusi yang memiliki aktivitas antibakteri dengan melihat perubahan warna bercak noda pada kromatogram. Senyawa tersebut dapat berupa flavonoid, tanin, atau saponin. Pemantauan penampakan bercak KLT akan dilakukan menggunakan sinar UV dengan panjang gelombang $254 \mathrm{~nm}$ dan $365 \mathrm{~nm}$ [11].

\section{Kadar Hambat Minimum (KHM)}

Penentuan KHM dilakukan dengan metode dilusi di dalam microplate. $1 \mathrm{ml}$ agar broth dipipet ke dalam masingmasing sumur di microplate. Kemudian dimasukkan ekstrak etanol E. bulbosa dengan 5 konsentrasi yang dioptimasi pada penelitian. Lalu disemua sumur dimasukkan biakan bakteri yang ingin diuji sebanyak $10^{6} \mathrm{cfu} / \mathrm{ml}$. Inkubasikan selama 24 jam pada suhu $37^{\circ} \mathrm{C}$. Lalu amati perubahan kekeruhan, adanya perubahan kekeruhan menandakan terdapat pertumbuhan bakteri untuk mempermudah visualisasi diteteskan 10 uL MTT, adanya perubahan warna menandakan adanya pertumbuhan bakteri. KHM diinterpretasikan pada tabung konsentrasi terendah pertama yang tidak menunjukkan pertumbuhan [12].

\section{Analisis Statistik}

Pengolahan data dilakukan setelah semua data dikumpulkan. Pengolahan data dilakukan secara manual dengan mengikuti langkah-langkah berupa editing, coding, dan tabulating. Pengolahan data dilakukan dengan menggunakan Microsoft Excel 2010.

\section{HASIL}

\section{Kromatografi Lapis Tipis (KLT)}

Hasil KLT ekstrak etanol $E$. bulbosa dengan menggunakan berbagai fase gerak menunjukkan pemisahan dan kenaikan noda yang bervariasi, seperti yang ditunjukkan pada Tabel 1. Profil kromatogram ekstrak etanol E. bulbosa setelah pemberian pereaksi ditunjukkan pada Tabel 2.

Tabel 1. Nilai Rf kromatogram ekstrak etanol E. bulbosa

\begin{tabular}{|c|c|c|c|c|c|}
\hline \multirow[b]{2}{*}{ Sinar } & \multirow[b]{2}{*}{ Noda } & \multicolumn{4}{|c|}{ Nilai Rf } \\
\hline & & $\begin{array}{l}\text { BAA }^{(a)} \\
(4: 1: 5)\end{array}$ & $\begin{array}{l}\text { EMA }^{(b)} \\
(6: 2: 4)\end{array}$ & $\begin{array}{c}\text { KEA }^{(\mathrm{c})} \\
(0,5: 9: 0,5)\end{array}$ & $\begin{array}{l}\mathrm{NE}^{(\mathrm{d})} \\
(4: 1)\end{array}$ \\
\hline \multirow{3}{*}{ UV 254} & 1 & 0,53 & 0,71 & 0,89 & 0,24 \\
\hline & 2 & 0,86 & 0,85 & - & - \\
\hline & 3 & - & - & - & - \\
\hline \multirow{7}{*}{ UV 365} & 1 & 0,52 & 0,70 & 0,11 & 0,03 \\
\hline & 2 & 0,74 & 0,79 & 0,22 & 0,08 \\
\hline & 3 & 0,87 & 0,88 & 0,56 & 0,17 \\
\hline & 4 & - & - & 0,73 & 0,26 \\
\hline & 5 & - & - & 0,78 & - \\
\hline & 6 & - & - & 0,86 & - \\
\hline & 7 & - & - & 0,89 & - \\
\hline
\end{tabular}

Keterangan:

(a) $B A A=$ butanol/ asam asetat/ air (4:1:5); (b) EMA = etil asetat/ metanol/ air (6:4:2); (c) KEA = kloroform/ etil asetat/ asam formiat (0,5:9:0,5); (d) $N E=n$-heksan/ etil asetat (4:1) 
Tabel 2. Profil kromatogram ekstrak etanol E. bulbosa setelah pemberian pereaksi

\begin{tabular}{|c|c|c|c|c|}
\hline \multirow[b]{2}{*}{ Golongan } & \multicolumn{4}{|c|}{ Nilai Rf } \\
\hline & $\begin{array}{l}\text { BAA }^{(a)} \\
(4: 1: 5)\end{array}$ & $\begin{array}{l}\operatorname{EMA}^{(\mathbf{b})} \\
(6: 2: 4)\end{array}$ & $\operatorname{KEA}^{(\mathrm{c})}(0,5: 9: 0,5)$ & $\begin{array}{l}N^{(d)} \\
(4: 1) \\
\end{array}$ \\
\hline \multirow{6}{*}{$\begin{array}{c}\text { Senyawa } \\
\text { mengandung gula } \\
\text { (UV365) }\end{array}$} & 0,21 & & 0,25 & \multirow{6}{*}{$\begin{array}{l}0,17 \\
0,29 \\
0,33\end{array}$} \\
\hline & 0,56 & & 0,48 & \\
\hline & 0,78 & $0, / 8$ & 0,63 & \\
\hline & 0,80 & 0,82 & 0,73 & \\
\hline & 0,82 & & 0,76 & \\
\hline & 0,88 & & 0,82 & \\
\hline \multirow{2}{*}{$\begin{array}{l}\text { Senyawa alkaloid } \\
\text { (sinar tampak) }\end{array}$} & 0,56 & \multirow{2}{*}{$\begin{array}{l}0,82 \\
0,94\end{array}$} & \multirow{2}{*}{$\begin{array}{l}0,13 \\
0,81\end{array}$} & 0,29 \\
\hline & $\begin{array}{l}0,78 \\
082\end{array}$ & & & 0,33 \\
\hline \multirow{5}{*}{$\begin{array}{l}\text { Senyawa terpen- } \\
\text { steroid (UV365) }\end{array}$} & \multirow{5}{*}{$\begin{array}{l}0,56 \\
0,85\end{array}$} & & & 0,16 \\
\hline & & 0,54 & 0,73 & 0,29 \\
\hline & & 0,76 & 0,82 & 0,33 \\
\hline & & 0,82 & 0,89 & 0,38 \\
\hline & & \multirow{4}{*}{$\begin{array}{l}0,82 \\
0,94\end{array}$} & & 0,69 \\
\hline \multirow{3}{*}{$\begin{array}{c}\text { Senyawa flavonoid } \\
\text { (UV365) }\end{array}$} & 0,56 & & 0,11 & 0,11 \\
\hline & 0,72 & & 0,82 & 0,29 \\
\hline & 0,89 & & 0,89 & 0,33 \\
\hline
\end{tabular}

Keterangan:

(a) $B A A=$ butanol/ asam asetat/ air (4:1:5); (b) EMA = etil asetat/ metanol/ air (6:4:2); (c) KEA = kloroform/ etil asetat/ asam formiat (0,5:9:0,5); (d) $N E=n$-heksan/ etil asetat (4:1)

Tabel 3. Hasil analisis golongan senyawa yang memiliki aktivitas antibakteri S. aureus (MRSA) pada ekstrak etanol E. bulbosa

\begin{tabular}{ccccc}
\hline & \multicolumn{4}{c}{ Nilai Rf Pada Zona Hambat } \\
\cline { 2 - 5 } Golongan Senyawa & $\mathbf{B A A}^{(\mathbf{a})} \mathbf{( 4 : 1 : 5 )}$ & $\mathbf{E M A}^{(\mathbf{b})}(\mathbf{6 : 2 : 4 )}$ & $\mathbf{K E A}^{(\mathbf{c})}(\mathbf{0 , 5 : 9 : 0 , 5 )}$ & $\begin{array}{c}\mathbf{N E}^{(\mathbf{d})} \\
(\mathbf{4 : 1})\end{array}$ \\
\hline mengandung gula $^{(\mathrm{e})}$ & 0,82 & 0,82 & 0,82 & 0,33 \\
alkaloidd $^{(\mathrm{f})}$ & 0,82 & 0,82 & - & 0,33 \\
terpen-steroid $^{(\mathrm{g})}$ & - & 0,82 & 0,82 & 0,33 \\
flavonoid $^{(\mathrm{h})}$ & 0,82 & - & 0,82 & 0,33 \\
\hline
\end{tabular}

Keterangan:

(a) $B A A=$ butanol/ asam asetat/ air (4:1:5); (b) EMA = etil asetat/ metanol/ air (6:4:2); (c) KEA = kloroform/ etil asetat/ asam formiat (0,5:9:0,5); (d) $N E=n$-heksan/ etil asetat (4:1); (e) reagen anisaldehid dibawah sinar UV $365 \mathrm{~nm}$; $(f)$ reagen Dragendorf pada sinar tampak; $(g)$ reagen Liebermann-Burchard dibawah sinar UV $365 \mathrm{~nm}$; (h) reagen $\mathrm{AlCl}_{3}$ dibawah sinar UV $365 \mathrm{~nm}$

\section{Bioautografi KLT}

Tabel 3 menunjukkan hasil analisis golongan senyawa yang memiliki aktivitas antibakteri pada ekstrak etanol E. bulbosa. Pada penelitian ini ditemukan bahwa ekstrak etanol E. bulbosa memiliki potensi aktivitas antibakteri yang baik terhadap $S$. aureus (MRSA) karena memiliki angka KHM sebesar 1 $\mathrm{mg} / \mathrm{mL}$.

\section{PEMBAHASAN}

Hasil Kromatografi Lapis Tipis (KLT)

Pada ekstrak etanol E. bulbosa ditemukan noda-noda pada plat KLT yang terpisah dengan cukup baik dengan menggunakan eluen kloroform/ etil asetat/ asam formiat $(0,5: 9: 0,5)$. Hal ini berarti bahwa senyawa-senyawa pada ekstrak etanol E. bulbosa adalah senyawa-senyawa polar atau semi non- 
polar karena kloroform, etil asetat dan asam formiat adalah pelarut polar. Dari keempat eluen yang digunakan sebagai larutan pengembang, n-heksan/etil asetat (4:1) tidak menunjukkan pemisahan yang sempurna pada ekstrak tanaman obat, jika dibandingkan dengan eluen yang lain yaitu butanol/asam asetat/air (4:1:5), kloroform/etil asetat/asam formiat $(0,5: 9: 0,5)$, dan etil asetat/metanol/air $(6: 4: 2)$.

Identifikasi terpenoid dan steroid dilakukan dengan menggunakan pereaksi Lieberman-Burchard. Timbulnya warna merah hingga ungu menandakan adanya triterpenoid, sedangkan warna hijau menunjukkan adanya senyawa steroid. Identifikasi senyawa golongan flavonoid dilakukan dengan menggunakan pereaksi $\mathrm{AlCl}_{3}$. Bila timbul warna hijau kekuningan pada penyemprotan menunjukkan keberadaan senyawa flavonoid pada KLT. Setelah pemberian pereaksi untuk mengidentifikasi 4 golongan senyawa yaitu golongan senyawa mengandung gula, alkaloid, terpen-steroid dan flavonoid ditemukan bahwa ekstrak etanol E. bulbosa memiliki semua golongan senyawa ini.

Hasil KLT ekstrak etanol $E$. bulbosa pada penelitian ini dengan menggunakan berbagai fase gerak menunjukkan pemisahan dan kenaikan noda yang bervariasi. Pemisahan senyawa yang terbaik dalam KLT memiliki ciri yaitu terbentuknya bercak yang banyak dan terpisah dengan jelas.

Dengan menggunakan eluen butanol/ asam asetat/ air (4:1:5) pada ekstrak etanol E. bulbosa ditemukan noda plat KLT yang terpisah dengan baik. Hal ini berarti bahwa senyawa pada ekstrak etanol E. bulbosa bersifat polar, karena butanol dan asam asetat adalah pelarut polar, sehingga dengan pelarut ini senyawa-senyawa yang polar dan semi non polar dapat terpisahkan pada plat KLT setelah dilakukan elusidasi.

Dengan menggunakan eluen etil asetat/ metanol/ air (6:4:2) pada ekstrak etanol E. bulbosa ditemukan noda plat KLT yang terpisah dengan baik. Hal ini berarti bahwa senyawa pada ekstrak etanol E. bulbosa bersifat polar, karena etil asetat dan metanol adalah pelarut polar. Dengan menggunakan eluen kloroform/etil asetat/asam formiat (0,5:9:0,5) pada ekstrak etanol E. bulbosa ditemukan noda plat KLT yang terpisah dengan baik. Hal ini berarti bahwa senyawa pada ekstrak etanol E. bulbosa bersifat polar atau semi non polar, karena kloroform, etil asetat dan asam formiat adalah pelarut polar.

Dengan menggunakan eluen nheksan/ etil asetat (4:1) pada ekstrak etanol E. bulbosa ditemukan noda plat KLT yang terpisah dengan cukup baik. Hal ini berarti bahwa senyawa pada ekstrak etanol E. bulbosa bersifat non polar, karena n-heksan adalah pelarut non polar.

Secara umum ditemukan bahwa kromatogram yang menggunakan fase gerak n-heksan/ etil asetat (4:1) menunjukkan profil noda yang kurang dibandingkan dengan profil kromatogram yang lain, baik pada pengamatan dibawah sinar UV 254 maupun dengan menggunakan sinar UV 365. Hal ini dimungkinkan karena senyawa yang terdapat dalam ekstrak etanol E. bulbosa lebih banyak mengandung senyawa non polar sehingga tidak terlalu larut dalam nheksan, yang merupakan pelarut non polar.

Hasil ini sesuai dengan penelitian KLT pada ekstrak etanol E. bulbosa lainnya, dimana skrining fitokimia menggunakan metode spot tes menunjukkan bahwa ekstrak etanol $E$. bulbosa mengandung senyawa kuinon dan triterpenoid. Skrining dengan 
pereaksi Lieberman-Buchard menunjukkan hasil berwarna merah, yang berarti menganding senyawa golongan triterpenoid. Skrining golongan dengan pereaksi eter menunjukkan hasil warna terekstrak, ditambah $\mathrm{NaOH}$ 5\% warnanya menghilang, dan ditambah $\mathrm{HCl}$ warnanya muncul kembali, yang berarti mengandung senyawa golongan kuinon [13].

Hasil ini juga sesuai dengan penelitian KLT lainnya yang berhasil mendeteksi adanya noda menggunakan eluen kloroform/ metanol (9:1). Seluruh noda dideteksi menggunakan detektor UV dan semprotan vanilin. Ekstrak tumbuhan mengandung banyak komponen yang dapat terlihat dalam sinar tampak atau dibawah sinar UV. Reagen penyemprot kromatografik juga berguna dalam menunjukkan tipe komponen yang berbeda dan untuk memastikan komponen apa yang ada di dalam ekstrak tumbuhan. Hasil KLT menunjukkan ada total 10 noda yang terdeteksi menggunakan eluen kloroform/ metanol (9:1) dalam fase gerak, yang tercatat seragam dengan $\mathrm{Rf}$ sebesar 1,0; 0,90; 0,$77 ; 0,51$ dan 0,42 [14].

\section{Hasil Bioautografi KLT}

Hasil bioautografi KLT pada ekstrak etanol E. bulbosa ditemukan golongan senyawa mengandung gula, alkaloid, terpen-steroid dan flavonoid memiliki potensi aktivitas antibakteri terhadap $S$. aureus (MRSA). Pada pemeriksaan bioautografi ditemukan bahwa ekstrak etanol E. bulbosa dapat menghambat pertumbuhan bakteri yang diujikan yaitu $S$. aureus (MRSA). Bioautografi merupakan metode yang spesifik untuk mendeteksi bercak pada kromatogram hasil KLT yang mempunyai aktivitas antibakteri. Dasar metode ini adalah tehnik difusi agar, dimana senyawa antibakteri berpindah dari plat KLT ke medium agar yang telah mengandung bakteri. Setelah melalui proses inkubasi selama 24 jam, akan tampak zona jernih yang tidak ditumbuhi bakteri pada titik-titik tertentu yang mengandung senyawa antibakteri.

Bioautografi masih merupakan teknik yang berguna dalam mengungkap komponen yang mengandung aktivitas antibakteri. Hasil bioautografi KLT penelitian ini pada ekstrak etanol $E$. bulbosa ditemukan golongan senyawa mengandung gula, alkaloid, terpensteroid dan lavonoid memiliki potensi aktivitas antibakteri terhadap $S$. aureus (MRSA). Hasil ini sesuai dengan penelitian bioautografi KLT lainnya dengan menggunakan ekstrak butanol $E$. bulbosa. Terhadap S. aureus, ekstrak butanol menunjukkan zona inhibisi yang jelas (panjang $78 \mathrm{~mm}$ dan lebar $36 \mathrm{~mm}$ ) sepanjang plat KLT [15].

Hasil ini sesuai dengan analisis GC-MS pada ekstrak etil asetat $E$. bulbosa yang berhasil mengidentifikasi komponen, yang sebagian besar merupakan fenolik. Sebagian besar komponen yang terdeteksi dari analisis GC-MS ekstrak etil asetat E. bulbosa menunjukkan bioaktivitas potensi antibakteri. Aktivitas antibakteri $E$. bulbosa dapat disebabkan oleh lebih banyak komponen lain, diluar komponen yang berhasil diungkap dalam hasil penelitian tersebut [14].

\section{Hasil Pengukuran Kadar Hambat Minimal (KHM)}

Pada penelitian ini ditemukan bahwa ekstrak etanol E. bulbosa memiliki potensi aktivitas antibakteri yang baik terhadap $S$. aureus (MRSA) dengan angka KHM sebesar $1 \mathrm{mg} / \mathrm{mL}$. Hasil penelitian ini sesuai dengan penelitian aktivitas antibakteri ekstrak $E$. bulbosa terhadap beberapa bakteri grampositif seperti $S$. aureus ATCC 23235 dan 
27664 dengan angka KHM antara 120$125 \mu \mathrm{g} / \mathrm{mL}$ dan angka KBM (kadar bakterisidal minimal) antara 250-1000 $\mu \mathrm{g} / \mathrm{mL}$ [5]. Hasil penelitian ini juga sesuai dengan penelitian aktivitas antibakteri ekstrak E. bulbosa terhadap bakteri multidrug-resistant, yaitu Oxacillin-resistant S. aureus (ORSA). Aktivitas antibakteri dilakukan dengan metode difusi disk dan pengukuran KHM dengan metode mikrodilusi. E. bulbosa menunjukkan aktivitas terhadap ORSA pada KHM $125 \mu \mathrm{g} / \mathrm{L}$ [16].

Hasil penelitian ini sesuai dengan penelitian ekstrak E. bulbosa terhadap Methicillin-resistant S. aureus (MRSA) dengan angka KHM antara 62,5-1000 $\mu \mathrm{g} / \mathrm{mL}$. Pemberian ekstrak E. bulbosa selama 12 jam dengan 2 KHM dan 4 KHM akan membuat sel membesar dan ketebalan membran sel meningkat. Hal tersebut akan menimbulkan denaturasi sitoplasma dan merusak membran serta menyebabkan kerusakan sel $S$. aureus. Kurva pertumbuhan bakteri yang diberikan ekstrak sebesar 4 KHM menunjukkan 5 log reduksi dibandingkan dengan kontrol [5]. Hasil penelitian ini juga sesuai dengan penelitian aktivitas antibakteri dari ekstrak etanol kasar $E$. bulbosa terhadap serangkaian bakteri, termasuk S. aureus ATCC 12600. Hasil penelitian ini menunjukkan bahwa ekstrak etanol E. bulbosa memiliki aktivitas antibakteri yang lebih baik terhadap gram-positif dibanding dengan gram-negatif [17].

Dari penjelasan tersebut, diduga $E$. bulbosa memiliki aktivitas antibakteri yang baik karena memiliki kandungan naphtoquinones, yang dapat mempengaruhi proses transport elektron dalam komponen sel bakteri [5]. Kandungan flavonoid di dalam $E$. bulbosa diduga juga memiliki mekanisme kerja sebagai antibakteri, yaitu dengan cara mendenaturasi protein sel dan merusak dinding sel bakteri hingga bakteri mati. Flavonoid juga dapat mempresipitasikan protein secara aktif dan merusak lipid pada membran sel melalui mekanisme penurunan tegangan permukaan membrane sel [18].

\section{KESIMPULAN}

1. Hasil KLT pada ekstrak etanol $E$. bulbosa menggunakan empat macam eluen, yaitu butanol/ asam asetat/ air (4:1:5), etil asetat/ metanol/ air (6:4:2), kloroform/ etil asetat/ asam formiat $(0,5: 9: 0,5)$, dan n-heksan/ etil asetat (4:1), seluruhnya dalam berbagai fase gerak menunjukkan pemisahan dan kenaikan noda yang bervariasi.

2. Setelah pemberian pereaksi untuk mengidentifikasi 4 golongan senyawa yaitu golongan senyawa mengandung gula, alkaloid, terpen-steroid dan flavonoid, ditemukan bahwa ekstrak etanol E. bulbosa memiliki semua golongan senyawa tersebut.

3. Hasil bioautografi KLT pada ekstrak etanol E. bulbosa ditemukan golongan senyawa mengandung gula, alkaloid, terpen-steroid, dan flavonoid memiliki potensi aktivitas anti bakteri terhadap S. aureus (MRSA).

4. Pada penelitian ini ditemukan bahwa ekstrak etanol E. bulbosa memiliki potensi aktivitas antibakteri yang baik terhadap S. aureus (MRSA) dengan angka KHM sebesar $1 \mathrm{mg} / \mathrm{mL}$.

\section{UCAPAN TERIMA KASIH}

Penelitian ini dibiayai oleh Balai Besar Penelitian dan Pengembangan Tanaman Obat dan Obat Tradisional, Badan Penelitian dan Pengembangan Kesehatan, Kementerian Kesehatan, Republik Indonesia melalui Penelitian Lanjutan Riset Tumbuhan Obat dan Jamu tahun 2016. 


\section{DAFTAR PUSTAKA}

[1]. World Health Organization, 2017. WHO publishes list of bacteria for which new antibiotics are urgently needed. http://www.who.int/mediacentre/news/rele ases/2017/bacteria-antibiotics-needed/en/

[2]. World Health Organization, 2017. Antimicrobial resistance. http://www.who.int/mediacentre/factsheets /fs194/en/

[3]. Kamath N, Swaminathan R, Desai N, 2016. Antibacterial activity of Indian medicinal plant Moringa oleifera against MRSA and Klebsiella Spp. (ESBL) which are commonly isolated bacteria in hospital environments, International Journal of Applied Research, 2(8), 515-517.

[4]. Ganapathy S, Karpagam S, 2016. In vitro evaluation of antibacterial potential of Andrographis paniculata against resistant bacterial pathogens Methicillin Resistant Staphylococcus aureus (MRSA) and Multiple Drug Resistant Escherichia coli (MDR E. coli), International Journal of Bioassays, 5(3), 4879-4881.

[5]. Insanu M, Kusmardiyani S, Hartati R, 2014. Recent Studies on Phytochemicals and Pharmacological Effects of Eleutherine americana Merr, Procedia Chemistry, 13, 221-228.

[6]. Kuntorini EM, Nugroho LH, 2010. Structural development and bioactive content of red bulb plant (Eleutherine americana): a traditional medicines for local Kalimantan people, Biodiversitas, 11(2), 102-106.

[7]. Efendi A, Ahmad I, Ibrahim A, 2015. Efek antimitosis ekstrak bawang dayak (Eleutherine americana L. Merr) terhadap sel telur bulu babi (Tripneustes gratilla Linn.), Jurnal Sains dan Kesehatan, 1(3), 99-104.

[8]. Departemen Kesehatan RI, 2008. Farmakope Herbal Indonesia, Edisi Pertama, Departemen Kesehatan RI, Jakarta.

[9]. Coyle MB, 2005. Manual of Antimicrobial Susceptibility Testing. American Society of Microbiology. Seattle.
[10]. Suleiman MM, McGaw LJ, Naidoo V, Eloff JN, 2010. Detection of Antimicrobial Compounds by Bioautography of Different Extracts of Leaves of Selected South African Tree Species, African Journal of Traditional Complementary and Alternative Medicine, 7(1), 64-78.

[11]. Choma IM, Jesionek W, 2015. TLC-Direct Bioautography as a High Throughput Method for Detection of Antimicrobials in Plants, Chromatography, 2, 225-238.

[12]. Shaheen AY, Sheikh AA, Rabbani M, Aslam A, Bibi T, Liaqat F, Muhammad J, Rehmani SF, 2015. Antibacterial activity of herbal extracts against multi-drug resistant Escherichia coli recovered from retail chicken meat, Pakistan Journal of Pharmacology Sciences, 28(4), 1295-1300.

[13]. Kuntorini EM, Astuti MD, Nugroho LH, 2010. Struktur anatomi dan aktivitas antioksidan bulbus bawang dayak (Eleutherine americana Merr.) dari daerah Kalimantan Selatan, Berkala Penelitian Hayati, 16, 1-7.

[14]. Rani VS, Nair BR, 2016. GC-MS analysis of ethyl acetate extract of Eleutherine bulbosa (Urban) Miller (Iridaceae), International Journal of Pharmaceutical Sciences and Research, 74(4), 1729-1733.

[15]. Padhi L, Panda SK, 2015. Antibacterial activity of Eleutherine bulbosa against multidrug-resistant Bacteria, Journal of Acute Medicine, 5, 53-61.

[16]. Saraiva RMC, da Silva Borges E, Ferreira FA, do Nascimento Brandao DL, Vieira ABR, dos Santos Vieira JM, 2012. Antibacterial activity of medicinal plants against multidrug-resistant bacteria, International Journal of Pharmaceutical Sciences and Research, 3(12), 4841-4847.

[17]. Ifesan BOT, Ibrahim D, Voravuthikunchai SP, 2010. Antimicrobial activity of crude ethanolic extract from Eleutherine americana, Journal of Food, Agriculture \& Environment, 8(3\&4), 1233-1236.

[18]. Syamsul ES, Supomo S, Wijaya H, Nugroho BA, 2015. Formulasi ekstrak etanol umbi bawang tiwai (Eleutherine americana) dalam sediaan krim anti acne, Traditional Medicine Journal, 20(3), 149157. 